\title{
Minas Çeraz'ın (Minasse Tcheraz) Avrupa Temasları ve Berlin Kongresi İzlenimleri
}

\author{
Minasse Tcheraz's Contacts of Europe and His Impressions of \\ Berlin Congress
}

Serdar Sakin*

\section{Özet}

Berlin Konferansı toplanmadan önce Ermeni milletinin isteklerini içeren bir muhtırayı konferansa katılacak devletlere önceden sunmak ve konferansta desteklerini sağlamak için Ermeni Patriği Nerses Varjabedyan Berlin'e bir heyet yollamıştır. Osmanlı Devleti'nin haberi olmadan gönderilen bu heyette eski patrik Mıgırdıc Kırımyan, Horin Narbey temsilci sıfatıyla, Minas Çeraz da kâtip ve tercüman göreviyle hazır bulunmuşlardır.

Söz konusu heyet 8 Mart 1878'de Istanbul'dan ayrilmış ve Avrupa seyahati Minas Çeraz tarafindan kaleme alınmıştır. Çeraz'in anlattıkları doğrultusunda sırasılyla İtalya, Roma, Londra ve Berlin'de temaslarda bulunmuşlardır. Bu temaslar bağlamında Italya'da Hariciye Nazırı Luigi Corti, Londra'da Lord Salisbury ile yapılan görüşmelere değinilmiştir. Avrupa gezisi sırasında yapılan görüşmelerde Ermenilerin Avrupalılarca bilinmedikleri görülmüştür. Buna dair çeşitli görüşmeler, yemek ziyafetlerinde, ziyaret edilen okullarda karşılaşılan durumlar örnek olarak sıralanmıştır. Ayrıca Avrupalıların Ermeniler hakkında az bilgi sahibi olmalarının nedenlerine değinilmiştir. Ermeni heyetinin gezisi sayesinde Ermeniler hakkında daha fazla bilgi sahibi olacaklarına işaret edilmiştir.

Nihayet Berlin Kongresi'nde kabul edilen 61. Maddenin Ermeniler için zarar değil fayda sağlayacağı, bunu gerçekleştirmek için Ermenilerin birlik ve beraberlik içinde yapması gerekenler belirtilmiştir.

Anahtar Kelimeler: Minasse Çeraz, Mıgırdıc Kırımyan, Nerses Varjabedyan, Ermeni Meselesi, Berlin Kongresi.

\begin{abstract}
Before Berlin Congress assembled, Armenian Patriarch Nerses Varjabedyan had sent a delegation to the Congress in order to present the countries participating in the Congress with a memorandum that contained the requests of Armenian people and to secure these countries'support throughout the Congress. The delegation, which was sent unknown to the Ottoman Empire, consisted of three members, i.e. former Patriarch Migirdic Kirimyan and Khoren Narbey as representatives, and Minasse Tcheraz as clerk and translator.

The delegation left Istanbul on 8 March, 1878, and situations and experiences they had during the aforementioned journey to Europe was written by Minasse Tcheraz. He stated that they made contacts in Italy, Rome, London and Berlin, respectively. In accordance with these contacts, he mentioned meeting with Foreign Minister Luigi Corti in Italy, and Lord Salisbury in London. By means of these meetings during the journey, it became apparent that Armenians were unknown to Europeans. Various meetings, dinner parties and situations encountered at schools they visited were given as examples to illustrate
\end{abstract}

* Doç. Dr., Erciyes Üniversitesi Edebiyat Fakültesi Tarih Bölümü, E-mail: serdar.sakin@gmail.com,

Akademik Bakış 237 Cilt 8 Sayı 16 Yaz 2015 
this fact. Moreover, reasons regarding Europeans' limited information about Armenians were stated. It was also indicated that thanks to the journey of the Armenian delegation, Europeans would have more information about Armenians.

Tcheraz eventually indicated that Article 61, which was accepted in Berlin Congress, would not cause any problems, instead provide benefits for Armenians, and also stated the required steps to be taken in unity so as to attain these benefits.

Keywords: Minas Tcheraz, Migirdic Kirimyan, Nerses Varjabedyan, The Armenian Question, Berlin Congress.

\section{Giriş}

1877-1878 Osmanlı- Rus Savaşı'nın son bulduğu sıralarda Ermeni Patriği Nerses Varjabedyan' ve Mateos İzmirliyan'ın başkanlıklarında Ermeni Meclisi gizli surette toplanarak Rus Çarı Grandük Nikola'ya verilmek üzere Eçmiyazin Katogikosluğuna bir muhtıra gönderilmesine karar vermiştir ${ }^{2}$. Muhtırada Çar Nikola'nın himayesinde Doğu Anadolu'da bir Ermeni Devleti kurulmasını teklif etmiştir ${ }^{3}$. Bu suretle savaş sonunda imzalanan 3 Mart 1878 tarihli Ayastefanos (Yeşilköy) Antlaşması'na Ermenilerle ilgili şu madde eklenmiştir:

Madde 16- Ermenistan'da ( Doğu Anadolu'da) Rus işgalinde bulunan ve Türkiye'ye geri verilecek olan toprakların Rus askerince boşaltılması, oralarda iki devletin (Türkiye ve Rusya'nın) iyi ilişkilerine zarar verebileceğinden, Babıâli Ermenilerin yaşadığı vilayetlerde yerel durumun gerektirdiği iyileştirmeleri ve islahatları zaman yitirmeden ve Kürtler ve Çerkezlere karşı Ermenilerin güvenliğini sağlamayı üzerine alır

Bu madde ile Rus etkisinin Doğu Anadolu'da arttığını gören İngiltere, Ayastefanos Antlaşması'nın Osmanlı ve Rus Devletleri arasında değil, vaktiyle Paris Konferansı'nda bulunmuş devletlerarasında tartışılması gerektiğini ileri

Akademik

Bakış

1 Mıgırdıç Kırımyan'ın istifası üzerine patrik seçildi. Ölümünden sonra yerine 1885'te Erzurum episkoposu Harutyan Vehabedyan patrik tayin olunmuştur. Hüdavendigar Onur, Ermeni Olayları Kronolojisi Milleti Sadıkadan Haykın Çocuklarına 3, Bilge Oğuz Yayınları, İstanbul Haziran 2006, s. 165-167; Turgay Uzun, "Osmanlı Devleti'nde Milliyetçilik Hareketleri İçerisinde Ermeniler", Osmanlı'dan Günümüze Ermeni Sorunu, Editör: Hasan Celal Güzel, Yeni Türkiye Yayınları, Ankara 2000, s. 90; Nerses Varjabedyan (1837-1889): Ermeni sorununu uluslar arası arenaya çıkaran ilk Ermeni milliyetçisi olarak tanınmaktadır. İstanbul'daki Ermeni Patrikhanesinin lideriydi. İstanbul'da gizlice Osmanlı aleyhinde faaliyet göstermekte, Berlin antlaşması öncesi İngiltere, Fransa, Almanya ve Amerika hükümetlerine gönderilen "Büyük Ermenistan Meselesi" müracaatını imzalamıştır. Türkiye'deki Türk karşıtı Ermeni örgütlerini maddi ve manevi olarak desteklemiştir. Aygün Attar, Ermeni Ulusalcılığının Siyasal Oluşumu, Ermeni Araştırmaları II. Büyük Kongresi, Ankara 29-30 Mayıs 2004, s. 6.

2 Esat Uras, Tarihte Ermeniler ve Ermeni Meselesi, Belge Yayınları, İstanbul 1987, s. 199.

3 Y.Atilla Şehirli, "Osmanlı Devleti'nde İhtilalci Ermeni Cemiyetlerinin Faaliyetleri ve Osmanlı Devleti'nin Aldığı Tedbirler", Dünden Bugüne Türk Ermeni Iliş̧kileri, Editör: İdris Bal-Mustafa Çufalı, Nobel Yayınları, Ankara 2003, s. 255.

4 Bilal N. Şimşir, Ermeni Meselesi 1774-2005, 2. Baskı, Bilgi Yayınları, Ankara 2005, s. 55-56. Bu madde ile ilk defa Ermeni adı uluslar arası bir antlaşmaya girmiştir. Şimşir, Ermeni Meselesi s.56. 
sürmüştür ${ }^{5}$. Çünkü Ermeniler üzerinde Rus nüfuzunun artması ve Rusya'nın doğuda itibar kazanmasının, İngiltere'nin hayati çıkarlarına ters düştüğü değerlendirilmiştir. İngiltere'nin Hindistan İmparatorluğu'na giden birinci yol Süveyş Kanalı'ndan, ikinci yol Doğu Anadolu'dan geçmekteydi. Bu sebeple Doğu Anadolu ve Ermeniler, Asya'da Rus- İngiliz rekabetinin bir düğüm noktası olarak görülmüştür6.

Bu suretle ortaya çıkan Berlin Kongresi düşüncesi üzerine Patrik Nerses Varjabedyan, Berlin'de yapılacak olan kongrede Ermeni isteklerini büyük devletlere sunmak üzere bir heyet oluşturmuştur. Bu heyette Daron Başpiskoposu ve Ermenilerin eski patriği Mıgırdıç Kırımyan ${ }^{7}$ ile Beşiktaş Başpiskoposu Horin Narbey millet mebusu sıfatıyla bulunmuşlardır. Maiyetlerine de kâtip ve tercüman olarak İstepan Papazyan ile Minas Çeraz ${ }^{8}$ verilmiştir. Çeraz, 17 yıl İngiltere'de King's College'de Ermeni Araştırmaları bölümünde profesör olarak çalışmıştır. Ermeni Vatanperver Cemiyeti'nin en önemli simalarındandır. Zira bu cemiyet siyasetçiler nezdinde etkin bir şekilde faaliyetlerde bulunmuş ve pek çok siyasetçiye kendi iddialarını kabul ettirme noktasında pek de zorluk çekmemiştir. Örneğin cemiyet olarak Osmanlı vilayetlerinde yaşayan Ermenilerin sözde uğradıkları zulüm ve düşmanlıklarla ilgili hazırladıkları bir raporu İngiltere Parlamentosu'nun bir salonunda Liberal Parti'ye mensup bazı milletvekillerine sunmuşlardır. Çeraz, 1889 yılının sonlarından itibaren Londra'da ayda iki kez Armenia dergisini yayınlamaya başlamıştır. 1893 yılında da İngiliz Ermeni Cemiyeti'ne üye olmuştur 9 .

Kırımyan Efendi ile Minas Çeraz birlikte Avrupa'ya gitmişler, Horin Narbey Çar 2. Alexandre ile görüşmek üzere Rusya'ya gitmiştir. İstepan

5 Davut Kılıç, "XIX. Asırda İngiltere'nin Orta doğu Politikasının Osmanlı Ermenilerine Yansıması”, Dünden Bugüne Türk Ermeni Îlişkileri, Editör: İdris Bal, Mustafa Çufalı, Nobel Yayınları, Ankara 2003, s. 235.

6 Şimşir, Ermeni Meselesi s. 56

7 (1820-1907) Kırımyan (Kırımyan, Kırımyan), 1869 yılında patrik seçildi. 1873'te istifa etti. Yerine Nerses Varjabedyan geçti. Hüdavendigar Onur, Ermeni Olayları Kronolojisi Milleti Sadıkadan Haykın Çocuklarına 2, Burak Yayınları, İstanbul 1999, s. 84-85. 1869-1874 yılları arasında İstanbul Ermeni patrikliği, 1878 Berlin Kongresi'ne Patrikhane tarafından gönderilen heyetin başkanlığı görevlerini yapmıştır. Hayatının tamamını bağımsız Ermenistan fikrine adayan Kırımyan 1892 yılında Eçmiyazin (Açmiyazin) Katogikosu seçilmiş ve 1907 yılında görevinin başındayken hayata gözlerini yummuştur. Fikrettin Yavuz, "Ermeni Kimliğinin İnşasında Bir Patrik Portresi: Mıgırdıç Hırımyan", Akademik Incelemeler, C.22, S.1, 2007, s. 32.

8 “...Berlin Konferansına Ermeniler lehine kulis faaliyetleri için eski Ermeni patriği Kırımyan ile birlikte giden Nurias Ceraz, 1879'da yayınladı̆̆ı..." Minas Çeraz ismi Kocabaş'ın makalesinde bu şekilde yer almıştır. Süleyman Kocabaş; “1878 Berlin Antlaşması'ndan Sonra İngiltere'nin Politikası", Hoşgörü Toplumundan Yol Ayrımına Ermeniler, C. IV, Erciyes Üniversitesi Yayınları, Kayseri 2007, s. 151. Bu durumu eleştirmemek mümkün değildir. Araştırmacı bir yazar olan bir kişinin yeterince araştıramadığının bir göstergesidir. Ferid Erden Boray'ın eserinde ise, Minas Cezar olarak yer almıştır. Ferit Erden Boray, Beyaz Ölüm Türkler ve Ermeniler, Kum Saati Yayınları, İstanbul 2004; Yahya Bağçeci'nin eserinde ise, Menas Tcheras olarak geçmektedir. Yahya Bağçeci, İngiltere'de Ermeni Propagandası (1878-1898), Yalın Yayıncılık, İstanbul 2013, s. 23.

9 Bağçeci, Ingiltere'de Ermeni..., s. 57, 71-72, 89, 105. 
Papazyan da sonradan Patrikhanenin şifresini alarak yola çıkmıştır ${ }^{10}$. Bütün üyeler 2 Haziran 1878'de Berlin'de buluşmuşlardır ${ }^{11}$.

Kırımyan Efendi ile Minas Çeraz, Berlin'e gitmeden önce muhtar bir Ermenistan hayalinin gerçekleşmesi için Avrupa başkentlerinde çeşitli faaliyetlerde bulunmuş, İtalya, Fransa ve İngiltere'de önemli devlet adamlarıyla görüşmüştür. Berlin Kongresi'nde büyük devletlerin Ermenilere destek vermelerini temine çalışmıştır. Ermeni Heyeti, 1878 senesi 8 Mart'ında İstanbul'dan ayrılmış ve 30 Temmuz'da geri dönmüştür. Kongre'nin ardından heyette kâtip ve tercüman olan Minas Çeraz, 5 aylık memuriyeti sırasında heyetin faaliyetlerini, yaşananları kaleme aldığı, değerlendirmelerde bulunduğu "Berlin Konferansı'ndan ne istifade eyledik" başlıklı ve Ermeni Patriği Nerses Varjabedyan namına telif olunan bir risale ( broşür ) yayınlamıştır. Çeraz, sağlığı müsait olmamasına rağmen bazı kişilerin Ermeni milli meselesinden bilgi almak istemeleri ve meselenin Berlin Konferansı'ndan kazandığı faydaları soranlara karşı yanlış bilgi verilmemesi adına başka bir ifadeyle Ermeni milletinin yanlış bilgilerle aldatılmaması için bu risaleyi yazma ihtiyacı hissettiğini belirtmiştir ${ }^{12}$. Ayrıca seyahati yalnız milli dava bakımından değil millet bakış açısıyla kaleme aldığını söylemiştir. Buna gerekçe olarak da Ermeni milletinin barış yoluna aşina olmaması nedeniyle en önemsiz ayrıntıyı bile bilmek istemesini, bunu bulamayınca da hakikatten bile şüphe edebilmesini göstermiştir ${ }^{13}$.

Ermeni Meselesi konusunda yapılan literatür değerlendirmesi sonucunda Minas Çeraz'ın yayınladığı broşüre dair herhangi bir çalışmaya ve değerlendirmeye rastlanmamıştır. İncelenen eserlerde Ermeni meselesinin tarihçesi, Ermeni isyanları, terör olayları, Ermenilerin büyük devletlerle ilişkileri gibi temel konuların ele alındığı görülmüştür. Genel olarak Ermeni Patriği Nerses'in Berlin Kongresi öncesi yolladığı heyetten ve bu heyetin kongrede yaptığı temaslardan bahsedilmiştir. Çeraz'ın seyahat notlarına ve değerlendirmelerine ilişkin bir bilgi verilmemiştir. Ermeni Meselesi'nin uluslar arası boyut kazandığı Berlin Kongresi öncesinde Ermenilere destek sağlamak için büyük devletlerle yapılan görüşmeler, devletlerin Ermeni kavramına ve Ermeni Meselesi'ne bakışı açısından önemli bilgileri içeren ve bizzat bu görüşmelerin içinde bulunan bir kişinin görüşlerinin yer aldığı broşürün yayınlanmamış olması bu makalenin yazılma amacını, problemini ortaya koymuştur.

Bu suretle makalede Minas Çeraz'ın İstanbul'dan ayrılışı, İtalya'daki görüşmeleri, Avrupa'nın Ermeni kavramını ve milletini değerlendirmeleri, son

10 Uras, age, s. 217, Mehmed Hocaoğlu, Arşiv Vesikalarıyla Tarihte Ermeni Mezalimi ve Ermeniler, Anda Dağıtım, İstanbul, 1976, s. 105.

11 Başbakanlık Osmanlı Arşivi (BOA), Fon Kodu: Yıldız Perakende Evrakı Sadaret Maruzatı (Y.PRK. A), Dosya No: 3, Gömlek No: 25, Belge. 1.

$12 B O A$, Fon Kodu: Y.PRK. A, Dosya No: 3, Gömlek No: 25, Belge. 1. Broşürün ilk sayfası için bkz. Ek-1.

13 BOA, Fon Kodu: Y.PRK. A, Dosya No: 3, Gömlek No: 25, Belge. 8. 
olarak da Ermenilerin Berlin Konferansı'ndan sağladıkları faydalara dair görüşleri belirtilecektir.

\section{İtalya İzlenimleri}

6 Mart 1878'de Ermeni Patriği Nerses Varjabedyan, Minas Çeraz'ın, Avrupa'ya gidecek heyette tercüman kâtip sıfatıyla bulunmasını istemiştir. Memuriyetin ücretsiz, güç ve tehlikeli olmasına rağmen Çeraz bu görevi kabul etmiştir ${ }^{14}$. Çeraz, heyetin başkanı Mıgırdıç Kırımyan ile birlikte 7 Mart'ta Odesa'ya hareket edecek olan Moskova vapuruna binmiştir. Ancak vapurun Kaptanı, Rusya hükümetinin Osmanlı ülkesinden Avrupa'ya rahip götürülmesini yasakladığını söyleyerek vapurdan inmelerini söylemiştir. Bu yüzden yolculuğa başlayamamışlardır ${ }^{15}$. Bu sefer 8 Mart'ta İtalya'nın Medit Rano vapuruna binerek Brindisi'ye doğru İstanbul'dan ayrılmışlardır. Ayrılmadan önce Çeraz, gerek çantasında ve gerekse üzerinde kendisini zarara ve ziyana uğratabilecek evrak bulunması nedeniyle kendi şahsından ziyade milleti için korktuğunu söylemiştir. Zaten bu nedenle kimliklerini gizleyerek gitmeye çalıştıkları görülmüş tür. Zira Başpiskopos Kırımyan'ın pasaportu Anadolu'ya gitmek gerekçesiyle Mıgırdıç, Minas Çeraz'ınki de ticaret amacıyla Hoca Bey'e gitmek üzere 35 yaşında Kirkoryan ismine verilmiştir. Korktuğu olmamış ve söz konusu evrak gümrük memuru tarafından şüpheli görülmemiş, bu halde tanınmadan vapura binmişlerdir ${ }^{16}$.

Vapur hareket ettikten sonra ertesi gün yani 9 Mart'ta henüz İstanbul'dan çok uzaklaşmış değillerdir. Heyet, gittiklerinin İstanbul'da duyulması karşısında bir telgraf emri ile dahi hemen tutuklanabileceklerini düşünmüşlerdir. Kendilerini bu düşünceye sevk eden husus da 9 Mart tarihidir. Çünkü söylendiğine göre bu tarihe Şarkta uğursuz gözüyle bakılmaktadır. Yakalanmamışlardır ancak korkuları yersiz de çıkmamıştır. Çünkü şiddetli bir fırtınaya tutulmuş$\operatorname{lardır}^{17}$. 10 Mart'ta Şire önlerine gelmişlerdir. Bu sırada Çeraz, yolculuğun devam ettiğini, kendisinin de Başpiskopos Kırımyan'ın Avrupa kabinelerine ileteceği belgeyi harfiyen tercüme etmekle uğraştığını belirtmiştir. 12 Mart'ta Brindisi'ye ulaşmışlardır. Roma'ya gitmek için trene binmeleri gerekirken tren gittiği için geceyi orada geçirmek üzere Hotel Oriantale'ye gitmişlerdir. Ertesi sabah yani 13 Mart sabah kahvaltısında kendilerine hizmet eden İtalyan bir genç Başpiskopos Kırımyan'a dikkatle bakmıştır. Bu genç dünyanın her bir tarafından gelen yabancı insanlar gördüğü halde ilk defa rahip kıyafetleri içinde bir Ermeni rahibine şahit olduğu için kibar bir şekilde durumu Çeraz'a sormuştur. Çeraz İtalyanca olarak "bu kişi Başpiskopos ve Asyalı'dır", deyince genç

14 BOA, Fon Kodu: Y.PRK. A, Dosya No: 3, Gömlek No: 25, Belge. 10. Broşürün Ermenistan ve İtalya kısmının başlangıcı için bkz. Ek-2.

$15 B O A$, Fon Kodu: Y.PRK. A, Dosya No: 3, Gömlek No: 25, Belge. 10.

$16 B O A$, Fon Kodu: Y.PRK. A, Dosya No: 3, Gömlek No: 25, Belge. 11.

$17 B O A$, Fon Kodu: Y.PRK. A, Dosya No: 3, Gömlek No: 25, Belge. 11. 
de: "Arkadaşınızın Kardinal ve daha sonra Papa olmasını iddia ederim" demiştir. Çeraz, garsonun bu duasını Başpiskopos Kırımyan'a tercüme ettiğinde bu sefer Başpiskopos, Ermenistan'ın Papalık görevinin kendisinde olduğunu garsona söylemesini istemiştir. Bunun üzerine İtalyan genç ile karşılıklı tebessüm etmişlerdir ${ }^{18}$. Kahvaltıdan sonra trene binerek Brindisi'den ayrılmışlardır ${ }^{19}$.

14 Mart'ta Roma'ya gelen Kırımyan ve Çeraz, Londra Oteli'ne yerleşmişlerdir. İkisinin tavsiyenamesi Başbakan Agostino Depretis adına yazılmıştır. Ancak Mart 1878'de İtalya'da hükümet değişikliği olmuş ve Depretis başbakanlıktan ayrılmıştır. Bu durumu Roma'da öğrenmişlerdir. Yine Roma'da kendileri adına kartvizit bastırmışlardır. Kırımyan'ın kartvizitinde "Daron Başpiskoposu ve Memalik-i Şahane Ermenilerinin eski Patriği Mıgırdıç Kırımyan”, Çeraz'ınkinde de "Ermeni Heyet-i Mebusesi Kâtibi Minas Çeraz" ifadeleri yazılmıştır. Çeraz, Kırımyan'ın kartvizitini Berlin'e gittiklerinde “Memalik-i Şahane Ermenilerinin murahhası Mıgırdıç Kırımyan" şeklinde değiştirmiştir ${ }^{20}$.

Çeraz, daha sonra resmi elbisesini giyerek Hariciye Nezareti müsteşarı Kont Korinelli'yi görmeye bakanlığa gitmiştir. Odacıya "Şaktan bir Hıristiyan heyeti gelmiştir. Hariciye Nazırına hitaben hamil olduğu tavsiyenameleri heyet adına kendilerine takdim etmek üzere buraya geldim" ifadelerini de yazdığg kartvizitini vermiştir. Birkaç dakika sonra müsteşar, Çeraz'ın yanına gelerek elini tutmuş ve Hariciye Nazırı Luigi Corti'nin kendisini çağırdığını, bu yüzden hemen çıkması gerektiğini söylemiştir. Ardından bütün gün vekil değişiklikleriyle uğraştığını, gece boyunca da uğraşmaya devam edeceğini dolayısıyla kendisiyle iki saat sonra veya ertesi günü görüşebileceğini eklemiştir. Bu sözler karşısında Çeraz, beklemeye karar vermiştir. Nihayet Müsteşar Korinelli gecikerek gelmiş, affını isteyerek odasına geçmişler ve Çeraz'a ne için geldiğini sormuştur. Ayrıntılıve net bir şekilde maruzatını anlattıktan sonra Çeraz müsteşara iki mektup ile bir muhtıra vermiştir. Nerses Varyabedyan tarafından imzalanan mektupların birisinde muhtıranın Ermeni milletinin isteklerini ve bunların dayanaklarını içerdiği, diğerinde de mebus sıfatıyla Başpiskopos Kırımyan'ın tavsiye edildiği yazılmıştır. Mektuplar usulüne uygun olarak resmi bir şekilde, muhtıra da kır-

Akademik

Bakış mızı mürekkeple yazıldığı için Çeraz, bunların içeriklerini gizliliklerinden dolayı layihasında yazamayacağını belirtmiştir ${ }^{21}$. Bu nedenle içerikleri hakkında bir bilgi edinilememiştir.

Mektupları ve tasarıyı verdikten sonra Çeraz, Şarkta 5 milyon Hıristiyan ahalisinin başkanı bulunan Ermenistan'ın eski patriği Mıgırdıç Kırımyan'ın, İstanbul Patriği Nerses Varjabedyan tarafından verilen bir tavsiyename ile Paris Antlaşması'nı imzalayan devletlerin kabinelerine tebliğ edilecek bir

18 BOA, Fon Kodu: Y.PRK. A, Dosya No: 3, Gömlek No: 25, Belge. 11.

$19 B O A$, Fon Kodu: Y.PRK. A, Dosya No: 3, Gömlek No: 25, Belge. 12.

20 BOA, Fon Kodu: Y.PRK. A, Dosya No: 3, Gömlek No: 25, Belge. 12.

21 BOA, Fon Kodu: Y.PRK. A, Dosya No: 3, Gömlek No: 25, Belge. 12. 
muhtırayı İtalya Hariciye Nezareti'ne takdim etmek üzere Roma'ya geldiklerini söylemiştir²2. Mektupların hükümet değişikliğinden önce 3 Mart 1878'de yani Baron Depretis görevdeyken onun adına yazıldığını belirtmiştir. Müsteşar işin önemini anladığı için Çeraz'a "Ermenistan Patriği şimdi Roma'da mıdır? Nerede konaklamaktadır?' Sorularını sormuştur. Çeraz da "39 numaralı Londra Oteli'nde" konakladığını söylemiştir. Müsteşar da en kısa zamanda kendilerini Hariciye Nazırı ile görüştüreceğini bildirmiştir ${ }^{23}$.

Ayrıldıktan sonra yaklaşık 4 saat içinde Çeraz, üzerinde acil işareti olup Minas Çeraz adına gönderilen ve adres olarak da Roma'da 39 numaralı Londra Oteli yazan bir zarf almıştır. Zarfın içinden yarınki (15 Mart) Çarşamba günü Hariciye Nazırı Kont Luigi Corti'nin Ermeni Heyeti Başkanı Kırımyan'ı Öğleden sonra saat 2'de kabul edeceğinin bildirildiği bir yazı çıkmıştır. Yazı doğrultusunda 15 Mart saat 14.00'da Başpiskopos Kırımyan rahip elbiseleriyle, Çeraz da başında kırmızı fesiyle Hariciye Nazırı'nın makamına çıkmışlardır. Çeraz, Kırımyan'ı Kont Corti'ye takdim ettikten sonra Corti, Kırımyan'a dönerek şunlar1 söylemiştir; "Şarkta 5 milyon Ermeni bulunduğu ve İstanbul Patriğinin Ermenistan' in patriği olduğu iddiaları açıkça yalandır. Bütün dünyada yaklaşık 2 milyon Ermeni vardır. Bunların ruhani başkanları da Rusya'da eski Ermenistan denilen Nahçıvan eyaletinde bulunan Eçmiyazin Patriğidir. Piskopos sıfatını taşımak isteyen bir Ermeni papazı bu nedenle Nahçıvan'a gitmek zorundadır. Bütün Osmanlı ülkesinde ancak 1 milyon Ermeni vardır ${ }^{24 "}$.

Ardından Çeraz'a dönerek Kırımyan'ın Avrupa lisanlarına aşina olup olmadığını sormuştur. Çeraz ise Kırımyan'ın sadece doğu dillerini bildiğini bu nedenle kendisinin Kırımyan'ın tercümanı olarak kabul edilmesini rica etmiştir. Kont Corti bu sefer Ermeni Heyetinin isteklerini sormuş, Çeraz buna karşılık elindeki resmi yazıyı okumuştur. Corti de "Ermeniler idari muhtariyet istiyorlar. Peki, bu muhtariyet Rumeli'de midir? Osmanlı Asyasında midır?" diye sorunca Başpiskopos Kırımyan soruyu "Rumeli'de Ermeniler vardır. Fakat Ermeni milletinin çoğunluğu Asya'da, Osmanlı Ermenistan'inda bulunduklarından orada idari muhtariyet istiyoruz" şeklinde cevaplamıştır ${ }^{25}$.

Daha sonra Kont Corti, verilen muhtırayı tam olarak anlamadı̆̆ını söyleyerek heyetten açıklama istemiştir. Bunun üzerine Başpiskopos Kırımyan açıklama yapmaya başlamış Çeraz da tercüme etmiştir. Buna göre izahatın ana hatları şöyle belirtilebilir: "Kırım Muharebesi'nden sonra Osmanlı ülkesinde hâkim olan millet ile azınlıklar arasında tam bir eşitlik sağlamak üzere Avrupa devletlerinin tavsiyesiyle 1856 tarihli Islahat Fermanı ilan edilmiştir. Eşitlik fikri pek güzelse de Osmanlı ülkesinde bunun uygulanması imkânsızdır. Zira bir halkın hürriyet ve eşitliğini ancak kendi hükümeti temin edebilir. Bu bakımdan Osmanlı hükümeti ruhani bir hükümettir. Üstelik devlet baş-

22 BOA, Fon Kodu: Y.PRK. A, Dosya No: 3, Gömlek No: 25, Belge. 12-13.

23 BOA, Fon Kodu: Y.PRK. A, Dosya No: 3, Gömlek No: 25, Belge. 13.

$24 B O A$, Fon Kodu: Y.PRK. A, Dosya No: 3, Gömlek No: 25, Belge. 13.

$25 B O A$, Fon Kodu: Y.PRK. A, Dosya No: 3, Gömlek No: 25, Belge. 14.

Akademik Bakış 243 Cilt 8 Sayl 16 Yaz 2015 
kanı olan padişah Halife sıfatıyla İslam dininin mutlak reisidir. Vekili bulunduğum 4 milyon Hıristiyan nüfusu olan Ermeni milleti asla zorluk çıkarmak arzusunda bulunmamıştır. Hiristiyanlar gerek Rumeli'de gerek Anadolu'da tahammül sinırlarının üzerinde bir zulme uğramışlardır26. Osmanlı Devleti ile Rusya arasındaki büyük savaşa (1877-1878 Savaşı) sebep olan, barlşl, güvenliği bozan, kargaşa meydana getiren de bahsi geçen zulümdür ${ }^{27}$. Ermeniler şimdiye kadar Osmanlı memurları ve Kürt eşkııaları tarafından diğer Hıristiyan kavimlerden daha fazla baskı altında tutulmuşlardır. Bundan sonra da Rus işgalinden kaçarak Rusya aleyhinde düşmanlik ve Hiristiyanlar aleyhinde intikam sevdaları besleyerek Asya'ya sığınan Bulgaristan katillerinin baskı ve zulümleri altında kalacaklardı28". Bu açıklamanın bazı kısımları hakkında değerlendirmeler yapmak yerinde olacaktır. Öncelikle Ermenilerin baskı altında tutuldukları ve zulme uğradıklarına dair bazı bilgiler paylaşılmalıdır. Gerek devlete sadakatleri gerek Türkçe konuşmaları ve Türk âdetlerini benimsemeleri Ermenilerin Osmanlı Devleti'nin çeşitli hizmetlerine atanmalarını sağlamıştır. XVI. Yüzyılda Vezir Mehmet Paşa, XVII. Yüzyılda Sadrazam Halil Paşa Ermeni asıllılardır. 1523'te Toroslar'da Gülek Kalesinde oturup kale hizmetinde çalışan 875 kişi Ermeni'dir. Saray kuyumculuğu yapan Düzyan ailesi, saray mimarlarından Balyan ailesi, Osmanlı hariciyesinde tercümanlık yapan ressam Manas ailesi, saray barutçu başılığında bulunan mühendis ve diplomat çıkaran Dadyan ailesi, Darphane müdürü Kazzaz Artin gibi ${ }^{29}$ Osmanlı Devleti'nin önemli mevkilerinde bulunan Ermeni ailelerine ve Ermenilere dair örnekleri çoğaltmak mümkündür. Yine Ohannes Apresyan isimli bir Ermeni subay, babasının emlak ve çiftlik sahibi varlıklı bir insan, çocukluk arkadaşlarının önemli bir kısmının çiftliklerinde çobanlık yapan Türk çocukları, Türklerin çoğunun fakir olduğunu, köylerinin yarı yarıya Türkler ile Ermenilerden oluştuğunu paylaşarak birlikte yaşama sanatının örneklerini sunmuştur ${ }^{30}$. Ayrıca Osmanlı Devleti Özveri ile çalışarak başarıya ulaşan, bu başarısı ile toplumu etkileyen kişileri din ve milliyet ayrımı yapmaksızın takdir etmekten geri durmamıştır. Devlet hizmetinde yararlılık, bağlılık ve fedakârlık gösterenleri çeşitli hediye ve ödüllerle taltif etmiştir. Bu cümleden olmak üzere 1848'de Piskopos Agop'a bir nişan-1 hümayun tevcih edilir-

Akademik

Bakış ken 1858'de Eçmiyazin katogikosluğuna tayin olunun Matteos'a birinci dereceden Mecidiye nişanı verilmiştir. 1869 yılında İstanbul Ermeni Patriği seçilen Mıgırdıç Kırımyan'a Mecidiye nişanı verilmiştir ki pek çok fotoğrafında göğsünde taşıdığı bu nişan hemen göze çarpmaktadır. Birkaç kez Osmanlıvatanse-

26 BOA, Fon Kodu: Y.PRK. A, Dosya No: 3, Gömlek No: 25, Belge. 14

27 BOA, Fon Kodu: Y.PRK. A, Dosya No: 3, Gömlek No: 25, Belge. 14-15.

$28 B O A$, Fon Kodu: Y.PRK. A, Dosya No: 3, Gömlek No: 25, Belge. 15.

29 Recep Çelik, "Osmanlı Bürokrasisinde Görev Yapan Ermeniler”, Hoşgörü Toplumunda Ermeniler, C. 4, Yayına Hazırlayanlar: Metin Hülagü, Şakir Batmaz, Süleyman Demirci, Gülbadi Alan, Erciyes Üniversitesi Yayınları, Kayseri 2007, s. 29-31.

30 Seyfullah Korkmaz, "Osmanlı Toplumunda Birlikte Yaşama Anılarından Seçmeler”, Hoşgörü Toplumunda Ermeniler, C. 4, Yayına Hazırlayanlar: Metin Hülagü, Şakir Batmaz, Süleyman Demirci, Gülbadi Alan, Erciyes Üniversitesi Yayınları, Kayseri 2007, s. 291-292. 
verliğine bağlılığını bildiren Patrik Nerses'e birinci dereceden Osmanî Nişanı verilmiştir ${ }^{31}$. Nihayet 19 Mart 1877 - 28 Haziran 1877 tarihleri arasında devam eden Osmanlı Devleti'nin ilk Meclis-i Mebusan'ında 120 milletvekilinin 12'si Ermeni'dir. Ermeni mebuslar toplamda 56 oturumda 245 kez söz almışlardır. Konuşmalar incelendiğinde Ermeni mebusların vatandaş olma bilinciyle devletin her sorunuyla ilgilendikleri, gayri Müslim vatandaşların haklarını koruma ve geliştirme çabaları dışında devleti bölmek gibi kaygıların olmadığı, Ermeni milletinin milli kimliğine yönelik açık bir ifadenin de bulunmadığı görülür ${ }^{32}$. O halde bahsi geçen zulmün nasıl yapıldı̆̆ının ortaya konması gerekir.

Tekrar Kırımyan'ın açıklamalarına bakıldığında şöyle devam ettiği görülecektir. "Osmanlı-Rus Savaşı, Paris Antlaşması'nı imzalayan devletlerin Şark Meselesi'ni çözümlemek üzere düzenleyecekleri bir kongre ile son bulacaktır. Osmanlı ülkesinde büyük bir Hiristiyan kavmini oluşturan Ermenilerin durumu kongrede temsilcileri bulunacak olan devletler tarafindan dikkate alınmadikça da Osmanlı Devleti tebaasindan olan 3 milyon Ermeni adına Şark Meselesi'nin kesinlikle çözümlenemeyeceğini arz ederim. Üstelik Ayastefanos Antlaşması'nın 16. Maddesi gereğince Osmanlı hükümeti Osmanlı Ermenistan'inın durumunu iyileştirmeye mecburdur. Fakat ıslahat kelimesi Osmanlı ülkesinde hüküm ve itibardan uzaktır. Ermeniler de Osmanlı Devleti'nin bu gerçek olmayan sözüyle yetinemezler. Onlar, Avrupa'daki diğer azınlıklarla aynı şart ve hakları isterler ve bunu Avrupa Kongresi'ne arza cesaret ederler. Şöyle ki, Slav kavminden sonra Ermenilerden daha kalabalık bir Hiristiyan kavmi yoktur. Ermeniler yirmi seneden fazla bir süre genel seçim esasına dayanan bir milli anayasaya sahip olduklarından gayr-1 Müslim tebaa içinde yalnız onlar idari muhtariyetin güzelliklerinden faydalanmaya muktedirdir. Bunun yanında Ermeniler, Asya'nın en ziyade medeni ve gelişmiş toplumunu temsil ederler. Ancak Ermeni milletinin ilim ve sanayi alanındaki gelişmesi hakkında susmayı tercih edeceksem de çaba ve devamlılı sayesinde eğitim alanında ulaşılan ilerlemenin derecesi hakkında saygıdeğer Kont Corti'ye bir fikir vermek isterim. Şöyle ki Yunan ve Latin yazarlarinin eserleriyle Italyan, Alman, Fransız ve Ingiliz yazarlarının meşhur bütün eserleri Ermeniceye tercüme edilmiştir. Asya'da Ermenilere bu konuda denk olan bir başka millet var midır? Osmanlı'nın Avrupa topraklarında Gulunan Bulgar, Boşnaklar ve Hersekliler Avrupa medeniyetine daha yakın bulundukları halde eğitimde bu kadar ilerleme kaydedebilmişler midir? Işte Ermeniler belirtilen bu özelliklerinden dolayı Ermenistan'in Rusya ya verilmeyecek olan kısmında Avrupa'dan idari muhtariyeti talep ederler"33". Konuşmanın bu kısmında da Minas Çeraz'ın ve Kırımyan'ın kendi içlerinde tutarlı olmadıkları görülmüştür. Çünkü 5 milyon Ermeni nüfusundan bahsederken Bakanın çıkışı karşısında Ermeni nüfusunu

31 Zeynep İskefiyeli, “Osmanlı Devleti tarafından Ermenilere Verilen Nişan ve Madalyalar", Hoşgörü Toplumunda Ermeniler, C. 4, Yayına Hazırlayanlar: Metin Hülagü, Şakir Batmaz, Süleyman Demirci, Gülbadi Alan, Erciyes Üniversitesi Yayınları, Kayseri 2007, s. 575, 579-581.

32 Ahmet Oğuz, "Osmanlı İmparatorluğu'nda İlk Demokrasi Denemesi ve Ermeni Mebuslar", Hoşgörü Toplumunda Ermeniler, C. 4, Yayına Hazırlayanlar: Metin Hülagü, Şakir Batmaz, Süleyman Demirci, Gülbadi Alan, Erciyes Üniversitesi Yayınları, Kayseri 2007, s. 249-250.

33 BOA, Fon Kodu: Y.PRK. A, Dosya No: 3, Gömlek No: 25, Belge. 15. 
4 milyona daha sonra da 3 milyona düşürmüşlerdir. Bu konuda bilimsel verilere bakmak gerekirse Marcel Leart'ın 1882 yılı Ermeni Patrikhanesi'nin istatistikleri doğrultusunda verdiği bilgiye göre Osmanlı coğrafyasında 2.660.000 Ermeni yaşamıştır ${ }^{34}$. Başbakanlık Arşivi'nde 1896-1897 yıllarına ait altı belgede Anadolu ve Rumeli'de 530.132 erkek ve 450.404 kadın nüfusu olmak üzere toplam 970.536 Ermeni nüfusu verilmekle birlikte, birkaç vilayet için "henüz tahriri ikmal edilmemiştir" kaydı düşürülmüştür. Buna göre verilen nüfusun bir miktar daha artacağı tabiidir. Vital Cuinet'in verdiği bilgilere göre Ermenilerin nüfusu 1.152.367'dir. Fransız Sarı Kitabı, Ermeni nüfusunu 1.475.011 olarak vermiştir. Görüldüğü üzere XIX. Yüzyıl sonlarıyla XX. Yüzyıl başlarında Osmanlı Devleti'ndeki Ermeni nüfusu 1.000.000 ile 1.500.000 arasında değişmektedir ${ }^{35}$.

Kırımyan'ın "Slav kavminden sonra Ermenilerden daha kalabalık bir Hiristiyan kavmi yoktur" sözünün de doğru olmadığını belirtmek gerekir.

Konuşma bu doğrultuda sona ermiştir. Hariciye Nazırı Kont Corti ile yapılan görüşmeden sonra Ermeni Heyeti, 17 Mart 1878'de Saint Lazar isimli resmi okulu ziyaret etmiştir. Bu ziyaret sırasında okul müdürü, Çeraz'ın yanına yaklaşarak öğrencilerin (Kırımyan'ı işaret ederek) arkadaşının dini davranışlarıyla ruhani elbisesinden etkilendiklerini ve bu kişinin ismini, milletini, memuriyetini ve ruhani sıfatını bilmek istediğini söylemiştir. Çeraz, Kırımyan'ın kartvizitini verince de müdür teşekkür etmiştir ${ }^{36}$.

Bu olaydan sonra aynı gün yani 17 Mart'ta trene binerek Paris'e doğru gitmek üzere Roma'dan ayrılmışlardır. Yaklaşık 40 saatlik bir yolculuktan sonra da 19 Mart'ta Paris'e ulaşmışlardır ${ }^{37}$.

\section{Avrupa İzlenimleri}

Çeraz, Paris'te Ermeni milletinden olup ilim ve eğitim sahibi Mösyö Edvar Doloryan isimli kişiyi görmek için 3 defa Kolej mektebine gitmiş fakat kendisini bulamamıştır. Bunun üzerine Başpiskopos Kırımyan ile kendi kartvizitini Mösyö Doloryan'a verilmek üzere orada bırakmıştır ${ }^{38}$.

Akademik

Bakış

Mıgırdıç Kırımyan ve Minas Çeraz, Avrupa'ya gittiklerinde orada Ermenilerin hiç bilinmediklerini görmüşlerdir. Bu açıdan Avrupalılar varlıklarından haberleri olmadıkları bir millet hakkında kayıtsız kalmışlardır³.

Çeraz, Ermenilerin bilinmediğine dair yaşadığı birkaç hatıra da kaleme almıştır. Bu hatıraları şöyle sıralayabiliriz: Çeraz, Viyana'da, bir gazete muhabi-

34 Kemal H. Karpat, Osmanl Nüfusu (1830-1914) Demografik ve Sosyal Özellikleri, Çeviren: Bahar Tırnakçı, Tarih Vakfı Yurt Yayınları, İstanbul 2003, s. 87.

35 Azmi Süslü, Ermeniler ve 1915 Tehcir Olayı, Yüzüncü Yıl Üniversitesi Yayınları, Van, 1990.

36 BOA, Fon Kodu: Y.PRK. A, Dosya No: 3, Gömlek No: 25, Belge. 16.

$37 B O A$, Fon Kodu: Y.PRK. A, Dosya No: 3, Gömlek No: 25, Belge. 16.

38 BOA, Fon Kodu: Y.PRK. A, Dosya No: 3, Gömlek No: 25, Belge. 9.

39 BOA, Fon Kodu: Y.PRK. A, Dosya No: 3, Gömlek No: 25, Belge. 9. 
rinden Ermeni meselesi hakkında bir yazı yazmasını rica etmiştir. Muhabir bu konuda Çeraz'dan açıklama istemiş ve Ermeni dili olup olmadığını sormuştur. Manchester'da bir gazete muhabirine tanıtılırken Çeraz'ın Müslüman Ermenisi mi yoksa Rum Ermenisi mi? Olduğu sorulmuştur. Öyle ki muhabir, Müslüman ve Musevi'nin, Ermeni olduğunu zannetmiştir. Berlin'de katıldıkları diplomasi ziyafetlerinde davet sahipleri Çeraz'ı Müslüman zannettiği için kendisine "ne kadar karılarınız var" diye sorarlarmış ${ }^{40}$. Yine Londra'da bulundukları sırada Bağdat İngiliz eski Konsolosu Mösyö Lyoness'in ziyafetine davet edilmişler$\operatorname{dir}^{41}$. Davette Çeraz'a refakat eden Madam Vazel oldukça kültürlü bir bayan olmasına rağmen sofraya oturduklarında "Osmanlı ülkesinde böyle sofra ve yemek ziyafetleriniz var mı? Çünkü orada erkek ve kadın aynı sofrada oturmazsınız" demiştir. Çeraz bu durumu "Vazel, benim Ermeni olduğumu biliyorsa da Hiristiyan olduğumu bilmemekteydi" şeklinde değerlendirmiştir ${ }^{42}$. Bu örneklerde sadece Ermenilerin değil Osmanlı kültürünün de yeterince bilinmediği ortadadır.

Roma'da Hariciye Nazırı Kont Luigi Corti, "Ermenilerin talep ettiği idari muhtariyet Rumeli'de midir Anadolu'da mıdır?' diye sormuştur. Bu soru Çeraz'a İstanbul'da elçilik yapmış olan bir kişi tarafından sorulmuştur. Londra'da Lord Salisbury'nin huzuruna çıktıklarında Başpiskopos Kırımyan memuriyetini Salisbury'e arz etmiştir. Huzurundan çıkarken Salisbury, Çeraz'a Ermeni heyetinin hangi dilde konuştuğunu sormuştur. Çeraz bu iki örneği "işte bu iki diplomat iki büyük milletin yönetim mekanizmasında bulundukları halde birinde Ermenilerin vatanı, diğerinde de dilleri hakkında hiç kesin bilgi yoktur" ifadeleriyle yorumlamıştır ${ }^{43}$. Diş İşleri Bakanı sıfatını haiz olan kişilerin muhatapları hakkında bilgi sahibi olmamaları bir eksiklik olarak yorumlanabilir.

Çeraz, Avrupalıların Ermeniler hakkında bilgi sahibi olmamalarının nedeni olarak Avrupalı seyyahların Ermeni vatanını bilmediklerini, çünkü bunlardan pek azının Anadolu coğrafyasında Ermenilerin yaşadığı yerlere seyahat ettiğini söylemiştir. Avrupalıların, şarkta seyahate çıktıklarında ancak İstanbul'u ve diğer bazı şehirleri gezdiklerini, bu şehirlerde de Ermenileri diğer milletlerden ayırmalarının mümkün olmadığını, zira Ermenilerin milli ahlaklarını terk edip yabancı gelenekleri benimsedikleri için Ermenilerle Türkler, Rumlar ve diğer milletler arasında bir fark bulunmadığını eklemiştir ${ }^{44}$. Bu sözlere karşı Avrupalı seyyahların yaptıkları seyahatlere dair birkaç bilgi vermek gerekirse Fransız seyyah Amedee Jaubert doğuya yaptığı seyahatini 1821 yılında Ermenistan'a ve İran'a Yolculuk başlığıyla kaleme almıştır. Seyahatinin amacını az sayıdaki bilgileri, Küçük Asya'nın kuzeyi, İran coğrafyası, doğunun diğer halklarının gelenekleri hakkında sahip olunan notlara eklemek şeklinde

40 BOA, Fon Kodu: Y.PRK. A, Dosya No: 3, Gömlek No: 25, Belge. 9.

41 BOA, Fon Kodu: Y.PRK. A, Dosya No: 3, Gömlek No: 25, Belge. 9.

42 BOA, Fon Kodu: Y.PRK. A, Dosya No: 3, Gömlek No: 25, Belge. 10.

43 BOA, Fon Kodu: Y.PRK. A, Dosya No: 3, Gömlek No: 25, Belge. 10.

44 BOA, Fon Kodu: Y.PRK. A, Dosya No: 3, Gömlek No: 25, Belge. 9.

Akademik Bakış 247 Cilt 8 Sayı 16 Yaz 2015 
ifade etmiştir. Almanya doğumlu Eduard Schulz, İran ve Van'da incelemeler yapmıştır. Charles Felix Marie Texier 1833 ve 1843 yıllarında iki seyahat yapmış ve seyahatlerinde Anadolu'nun çok büyük bir kısmını baştan başa gezip dolaşmıştır. Xavier Hommaire de Hell, Anadolu ve İran'daki antik şehirleri incelemiştir. Baron Felix de Beaujour, bütün Kafkas, Anadolu ve Mezopotamya bölgesini gezmiş, etnik grupların tanınması için bilgiler toplamıştır. Vital Casimir Cuinet, Trabzon, Erzurum, Bitlis, Van Diyarbakır, İstanbul, İzmit, İzmir, Biga, Ankara, Konya, Adana, Elazı ̆̆, Sivas, Bursa ve Kastamonu'yu gezerek notla almıştır. Le Compte de Cholet Armand Pierre, Ankara, Hacı Bektaş, Kayseri, Sivas, Erzincan, Van, Bitlis, Diyarbakır, Hasankeyf, İskenderun, Mersin, İzmir ve İstanbul'u dolaşmıştır. Şarka seyahat eden seyyahları çoğaltmak mümkündür ki bu seyyahlar ayrıntılı olarak eserlerinde Ermenilerin Anadolu’ya gelişi, kökeni, sosyal hayatları, dinleri, kıyafet ve ticaretleri, Ermeni kadınları gibi konuları anlatmışlardır ${ }^{45}$. O halde Çeraz'ın seyyahların Ermenilerin yaşadıkları bölgeleri gezmemeleri ve sadece birkaç şehri gezdikleri bilgisine şüpheyle bakmak gerekir.

Çeraz ikinci bir sebep olarak da Avrupa'ya giden Ermenilerin kendilerini yeterince tanıtmamasını göstermiştir. Gidenlerin de ya şahsi menfaatleri veyahut zevk-ü sefaları için gittiklerini belirtmiştir. Başka bir neden olarak da Avrupa'ya seyahat eden Ermenilerin kimliklerini gizlemesinden bahsetmiştir. Müslüman bir ülkeden geldikleri için milliyetlerini söyledikleri takdirde polisler tarafından canilere yapılan muameleye maruz kalabilecekleri için milliyetlerini gizleyerek Avrupalı gibi davrandıklarını ifade ederek Manchester, Viyana ve Londra'da birçok Ermeni papazının sivil elbiseli oldukları halde Rum papazlarının ruhanî kıyafetleriyle dolaşmalarını örnek göstermiştir ${ }^{46}$. Osmanlı Devleti topraklarında baskı ve zulüm altında yaşadıklarını söyleyen Çeraz, Avrupalıların da Müslümanlara canilere yapılan muameleyi reva gördüklerinden bahsetmektedir. Bu durumda Çeraz'ın tutarsızlığı ve yaşadığı ikilem görülmektedir.

Akademik

Bununla birlikte Avrupa hükümetleri kendilerine müracaat eden Ermeni heyetini hürmetle ve iyi şekilde karşılamışlardır. Örneğin Lord Salisbury Londra'da Ermeni heyetine İngiltere Kraliçesinin Ermenilerin memnun olmasını, barış ve asayiş içinde sabırla beklemelerini arzu ettiğini söylemiştir ${ }^{47}$.

Avrupalıların Ermenilere dair malumatlarının olmamasına rağmen Ermeniler hakkında bilgi aldıkları zaman Ermeni milletine muhabbet besleyeceklerini, çünkü heyetin Avrupa' da büyük yadigârlar bıraktığını hatta bu bakımdan heyeti görenlerin onu hiçbir vakit unutmayacaklarını belirtmiştir. Üstelik

45 Mustafa Oflaz, İsmail Mangaltepe, "XIX. Yüzyıl Seyyahlarının Eserlerinde Ermeniler ve Türk-Ermeni İlişkileri”, Hoşgörü Toplumunda Ermeniler, C. 4, Yayına Hazırlayanlar: Metin Hülagü, Şakir Batmaz, Süleyman Demirci, Gülbadi Alan, Erciyes Üniversitesi Yayınları, Kayseri 2007, s. 334-351.

46 BOA, Fon Kodu: Y.PRK. A, Dosya No: 3, Gömlek No: 25, Belge. 9.

47 BOA, Fon Kodu: Y.PRK. A, Dosya No: 3, Gömlek No: 25, Belge. 4. 
bıraktıkları bu izlenimin bir gün şarkta tecelli etmesinin şüphesiz olduğunu söyleyerek Ermenilerin yabancılardan medet ummayıp çıkarlarını kendilerinin savunmasını, Ermeni olduklarını ve daima Ermeni kalmaları gerektiğini, Ermenilerin birlik ve beraberlik içerisinde hareket ettiği takdirde esaretten kurtulacağını ifade ederek Avrupa seyahati izlenimlerini sonlandırmıştır ${ }^{48 "}$.

\section{Berlin Kongresi'ne Dair İzlenimler}

19. yüzyılın son çeyreğine kadar İngiltere'nin Orta Doğu politikası, İstanbul'u ve Türk Boğazlarını Rusya'ya karşı korumaktır ${ }^{49}$. Ancak Berlin Kongresi ile birlikte Türk-İngiliz münasebetlerinde yeni bir dönem başlamıştır. İngiltere artık Rusya'nın güneyine inerek, İngiliz İmparatorluğu'nu tehdit etmeyi, Osmanlı Devleti vasıtasıyla değil, bizzat kendisi somut tedbirler alarak önleme yoluna gitmeye karar vermiştir. Bu suretle, Osmanlı Devleti'nin topraklarının bir kısmının kontrolünü doğrudan doğruya kendi eline almayı ve Rusya vasıtasıyla egemen olacağı topraklar üzerinde tampon devletler kurmayı düşünmüştür ${ }^{50}$. Bu düşünce Berlin Kongresi'nde kendisini gösterecektir.

1878'de Berlin'de toplanan kongrede İngiltere'nin, Osmanlı Devleti'nin toprak bütünlüğünün korunması düşüncesini bırakıp, Osmanlı'nın parçalanmasını hızlandırma gayreti içine girdiği görülmüştür. Böylece parçalanan Osmanlı topraklarının kalıntıları üzerinde bir Ermenistan kurdurarak kendisine bağlı tampon bir devlet oluşturmak siyasetini izlemeye başlamıştır ${ }^{51}$. Zira 13 Temmuz 1878 günü imzalanan Berlin Antlaşması'nda Osmanlı Ermenileri ile ilgili olarak 61. Madde ${ }^{52}$ dikkat çekmiştir. Buna göre Osmanlı hükümeti,

48 BOA, Fon Kodu: Y.PRK. A, Dosya No: 3, Gömlek No: 25, Belge. 10.

49 Kemal Melek, Doğu Sorunu ve Milli Mücadele'nin Dış Politikası, Der Yayınları, İstanbul 1985, s. 14. Üçüncü Selim Dönemi'nde bölge uluslar arası güçlerin çatışma alanına dönüşmüştür. Orta Doğu İngiltere açısından sadece güç çatışma alanı değil aynı zamanda sömürgelere giden yol olmasıyla hayati nokta durumuna gelmiştir. Bekir Günay, “Değişen Dünya Denkleminde Sorunlu Türk Bölgeleri ve Çözüm Önerileri”, Avrupa'dan Asya'ya Sorunlu Türk Bölgeleri, Derleyen: Bekir Günay, 1. Baskı, IQ Kültür-Sanat Yayınları, İstanbul 2005, s. 68.

50 Seton-Watson, R.W., Disraeli, Gladstone and the Eastern Question, The Norton Library Printers, London 1972, s. 380-400, 490-500. 1815 Viyana Kongresi ile somut biçimler almaya başlayan ve Osmanlı topraklarının paylaşılması isteğinden başka bir şey olmayan Doğu Sorunu bu kongre ile bilfiil uygulanmaya başlanmıştır. Taner Akçam, "Sevr ve Lozan'ın Başka Tarihi”, Imparatorluktan Cumhuriyet'e Türkiye'de Etnik Çatışma, Derleyen: Erik Jan Zürcher, İletişim Yayınları, İstanbul 2005, s. 55. Kesin bir tarih verilememekle birlikte, 1897'den itibaren Londra'daki karar vericilerin Osmanlının taksimine artık razı oldukları kaydedilmektedir. Mim Kemal Öke, Musul Meselesi Kronolojisi (1918-1926), Türk Dünyası Vakfı Yayınları, İstanbul 1987, s. 10, 19. Yüzyılın son çeyreğinde Osmanlı hükümetinin siyasi durumundan istifade etmek isteyen devletler, özellikle Rusya ve İngiltere, Ermenileri siyasi ve iktisadi alet olmak üzere kullanmak emellerini beslemişlerdir. Süleyman Kani İrtem, Ermeni Meselesinin İ̧yüzü, Haz: Osman Selim Kocahanoğlu, Temel Yayınları, İstanbul 2004, s. 6.

51 İsmail Özçelik, Ermeni Sorunu ve Gerçekler, Gündüz Eğitim Yayınları, Ankara 2005, s. 82.

52 Taha Akyol, Ortak Acı 1915 Türkler ve Ermeniler, Doğan Kitap, İstanbul Nisan 2009, s. 51; Salih Altınok, Belgeleriyle 19. ve 20. Yüzyıl Başlarında Ermeni Sorunu, Kozan Matbaacılık, Ankara Nisan 2007, s. 127; Yahya Bağçeci; “Osmanlı Belgelerine Göre Berlin Antlaşması'ndan I. Dünya

Akademik Bakış 249 Cilt 8 Sayı 16 Yaz 2015 
Ermenilerin yaşadığı eyaletlerde yerel ihtiyaçların gerektirdiği ıslahatları geciktirmeden yapmayı, Çerkez ve Kürtlere karşı Ermenilerin huzur ve güvenliğini sağlamayı taahhüt etmiştir. Bu hususta alınacak önlemleri büyük devletlere bildirmeyi ve devletler de alınacak önlemleri dikkate almayı kabul etmişlerdir ${ }^{53}$.

Böylece Ermeni sorunu, uluslar arası siyasal sistemin gündemine girmiştir ${ }^{54}$. Burada dikkati çeken nokta, Ayastefanos ve Berlin Antlaşmaları'nın Ermenilerle ilgili maddeleri arasında Büyük devletlerin bakış açısına göre pek fark olmayışıdır. Yani İngiltere, Rusya'nın Doğu Anadolu'da itibar kazanmasının kendi çıkarları için zarar getireceğine inanarak harekete geçmiştir; meseleyi uluslar arası platformda gündeme getirmek suretiyle Rusya'yı ikinci plana atarken, kendisi öne çıkmıştır. Bununla birlikte 61. Maddeye konu olan Ermeniler duruma daha farklı bir zaviyeden bakmışlardır. Çeraz'a ait olan değerlendirmeler şöyledir: "Osmanlı-Rus Savaşı'ndan sonra Ermeni Patriği Nerses Varjabedyan, Rusya hükümetinden Ermenistan'a idari muhtariyet verilmesini istemiştir. Bu istek karşısında Rusya, Osmanlı Devleti ile imzaladığı Ayastefanos Antlaşması'na bir madde koydurmuştur. Bu madde ile Ermenilerin yaşadiğı yerlerde ıslahat yapilmasını ve Hiristiyan kavimlerinin emniyet ve asayişinin sağlanmasını temin etmiştir ${ }^{55}$. Berlin Antlaşması gereğince de Osmanlı Devleti bu doğrultuda alacağı tedbirleri Büyük Devletlere bildirmeye mecbur kalmıştır. Yani

Savaşı'na Kadar Fransa'nın Ermeni Politikası", Turkish Studies International Periodical For the Languages, Literature and History of Turkish or Turkic Volume 5/4 Fall 2010, s. 4; Yahya Bağçeci, "İngiltere Başbakanı Lord Salisbury ve Ermeni Meselesi”, Erciyes Üniversitesi Sosyal Bilimler Enstitüsü Dergisi, Kayseri 2010, s. 196; Hamza Bektaş, Ermeni Soykırım İddiaları ve Gerçekler, Uludağ Üniversitesi Atatürk İlkeleri ve İnkılâp Tarihi Uygulama ve Araştırma Merkezi Yayınları, S. 5, Bursa 2001, s. 34; Nejdet Bilgi, Ermeni Tehciri ve Boğazlıyan Kaymakamı Mehmet Kemal Bey in Yargılanması, Kök Sosyal ve Stratejik Araştırmaları Serisi, S. 16, Ankara 1999, s. 5; Nejat Göyünç, Türkler ve Ermeniler, Yeni Türkiye Yayınları, Ankara Şubat 2005, s. 101-102; Erdal İlter, Ermeni Kilisesi ve Terör, Kök Sosyal ve Stratejik Araştırmalar Merkezi Yayınları, S. 11, Ankara 1999, s. 41; Recep Karacakaya, Kaynakçalı Ermeni Meselesi Kronolojisi (1878-1923), Başbakanlık Devlet Arşivleri Genel Müdürlüğü, Osmanlı Arşiv Daire Başkanlığı Yayınları, S. 52, İstanbul 2001, s. 3; Davut Kılıç, Osmanlı İdaresindeki Ermeniler Arasındaki Dini ve Siyasi Mücadeleler, Avrasya Stratejik Araştırmalar Merkezi Yayınlar, Ankara 2000, s. 208-210; Bayram Kodaman, Ermeni Macerası (Tarihi ve Siyasi Bir Değerlendirme), Süleyman Demirel Üniversitesi Yayınları, S. 12, Isparta 2001, s. 47; Bayram Kodaman, Türkler-Ermeniler ve Avrupa, Süleyman Demirel Üniversitesi Yayınları, S. 31, Isparta 2003, s. 28-31; Nurşen Mazıcı, Uluslar Arası Rekabette Ermeni Sorununun Kökeni (1878-1920), Pozitif Yayınları, İstanbul Nisan 2005, s. 35; Halil Metin, Türkiye'nin Siyasi Tarihinde Ermeniler ve Ermeni Olayları, MEB, Ankara 2001, s. 73-74; Mehmet Saray, Ermenistan ve Türk-Ermeni İlişkileri, Atatürk Araştırma Merkezi Yayınları, Ankara 2005, s. 33-35; Eyüp Şahin, Yabancı Gözüyle Ermeni Meselesi, Askerlik Dairesi Başkanlığı Yayınları, Ankara 2001, s. 33-35. Kemal Beydilli, "Küçük Kaynarcadan Yıkılışa", Osmanlı Devleti Tarihi, Edit: Ekmeleddin İhsanoğlu, C. I, Zaman, İstanbul 1999, s. 110.

53 Başbakanlık Osmanlı Arşivi (BOA), Y.A.HUS., Belge No: 169/43. Berlin Antlaşması'nın 62. Maddesi ayin ve mezhep serbestliğinin mutlak şekilde devam edeceğini, din ve mezhep değişikliğinin hiç kimse için diğer haklarda bir değişiklik yaratmayacağını, herkesin din ve mezhebe bakılmadan mahkemelerde şahitlik edebileceğini, Osmanlı ülkesindeki konsolosların, dini kuruluşları ve hayratı resmen korumak hakları olacağını hükme bağlamıştır. Kamuran Gürün, Ermeni Dosyası, 7. Baskı, Remzi Kitabevi Yayınları, İstanbul 2005, s. 163.

54 Mim Kemal Öke, Ermeni Sorunu 1914-1923 (Devletin Dış Politika Araç Alternatifleri Üzerine Bir inceleme), TTK Yayınları, Ankara 1991, s. 79-80.

55 BOA, Fon Kodu: Y.PRK. A, Dosya No: 3, Gömlek No: 25, Belge. 3. 
Ermeni milleti kongreden zarar değil bilakis fayda görmüştür. Çünkü Ayastefanos ile Berlin Antlaşmaları arasında Ermeniler lehine büyük bir fark vardır. Zira Ayastefanos Antlaşması ile Osmanl Devleti, Ermenileri Kürt ve Çerkezlere karşı korumayı sadece Rusya'ya taahhüt etmiştir. Rusya'nın ise Şark Meselesi'ni bir an önce meydana çılkarmak için Ermeniler hakkında mezalim yapılmasına izin vermesi muntemeldir. Hâlbuki Berlin Antlaşması'na göre Osmanlı, bu konuda bütün Büyük Devletlere karşı mecbur, ayrica yalnız Rusya tarafindan boşaltılan yerlerde değil bütün Ermenistan bölgesinde islahat yapmak zorunda kalmıştır. Rusya, 93 Harbi sirasında ele geçirdiği toprakları Osmanlı'ya iade etmeseydi Berlin Antlaşması'nda Ermeni Meselesi'nden asla bahsedilmezdi. Üstelik Berlin'de Osmanlı Devleti'nin Ermenilerin emniyet ve asayişini temin için Avrupa devletlerine karşı sorumlu olduğu kayıt altına alınmıştır. Avrupa alınacak tedbirleri yeterli görmezse daha fazla ve etkili tedbirlerin alınmasını isteyebilir. Bu durumda Osmanlı Devleti sadece bir kere değil daima ıslahatlar yapmak zorundadır. Şimdi bu Berlin Antlaşması, Ayastefanos Antlaşması'nın Ermeniler lehine olan hükmünü feshetmemiş, aksine doğrulamıştır ${ }^{50 "}$. Çeraz, Berlin Kongresi'nin faydalarına odaklanmıştır. Sadece Rusya değil bütün büyük devletlerin garantörlüğünün kazanılmasından ve tüm Ermenistan topraklarında iyileştirmeler yapılacağından bahsederek olumlu düşünmeye çalışmıştır.

Çeraz, fikirlerine devamla şunları söylemiştir: "Rusya hükümeti, Kıbrıs Antlaşması'nın feshini ve hükümsüzlüğünü sağlamak için, Berlin Antlaşması'nın 61. maddesine istinaden Ermenistan'a müdahale ve Ermenilerin zulme uğramamış olmasını talep edecektir. Ingiltere hükümeti, bu müdahaleyi durdurmak üzere Ermenilere şikâyete mahal verilmemesine dikkat edecektir. Diğer taraftan Rusya, Osmanl Ermenilerini kendi tarafına çekmek için Rusya topraklarında bulunan Ermenilerin durumunu ve buna karşılık Ingiltere, Osmanlı Ermenilerine Türk tabiiyetini arzu ettirmemek için bunların durumlarının iyileştirilmesine gayret ve dikkat edecektir. Ermeniler, her yönden bundan istifade edecektir. İki büyük devlet arasındaki rekabetin sebebi ise Dicle ve Firat nehirlerinin kaynaklarına sahip olan Osmanli Ermenistani'nın Rusya'nın tasarrufunda olmasının Rusya'ya çok faydall, ingiltere'ye çok zararlı olmasıdır". Londra'daki Almanya elçisinin heyete söylediği "nehrin kaynağına hâkim olan nehre dahi hâkim olur 57" sözler de rekabetin sebebini teyit etmiştir. Ayastefanos Antlaşması ile Kafkasya'ya hâkim olan Rusya, Doğu Anadolu ve Balkanlarda da etkili olmuştur. Ancak bu durum geleneksel İngiliz politikasına ters düşmüştür. Çünkü Rus nüfuzunun yayılması sadece İngiltere'nin Hindistan'la olan bağlantısını tehditle kalmamış, aynı zamanda Orta Doğu'daki gücünü de zayıflatmıştır. Bu durum İngiltere'nin konuya müdahalesini gerektirmiştir. Nitekim Berlin Kongresi bu gerekçelerle ortaya çıkmış$\mathrm{t}^{5}{ }^{58}$. Çeraz'ın ifadelerinden yola çıktığımızda da Ermenilerin Rusya ile İngiltere arasındaki durumu çok iyi tespit ettikleri ve bundan azami ölçüde yararlanmaya çalıştıkları ortadadır.

56 BOA, Fon Kodu: Y.PRK. A, Dosya No: 3, Gömlek No: 25, Belge. 4.

57 BOA, Fon Kodu: Y.PRK. A, Dosya No: 3, Gömlek No: 25, Belge. 5.

58 Halil Özşavlı, "Başlangıçtan I. Dünya Savaşına Kadar Rus-Ermeni İlişkileri", The Journal of Academic Social Science Studies (JASSS), C. 5, S. 2, Nisan 2012, s. 260.

Akademik Bakış 251 Cilt 8 Sayı 16 Yaz 2015 
Çeraz, değerlendirmelerine Berlin Kongresi'nin Ermeniler lehine olumlu yönlerini sıralayarak Ermenilerin millet olarak yapmaları gerekenleri tavsiye şeklinde olumsuz düşünmeye gerek olmadan anlatarak devam etmiştir. "Bu kadar fayda sağlandıktan sonra milletin üzülmesinin bir anlamı yoktur. Üstelik Patrik Efendi Ermenistan için idari muhtariyet istemişse de Avrupa devletleri bu isteği kabul etmemişlerdir. Hangi millet Berlin Konferansı kararlarından memnun olmuştur? Acaba Ermeniler, muhtariyet verildiğinde kendi kendine geçinebilecek halde miydiler? Şunu açıça beyan edebilirim ki; Avrupalilar muhtariyet vermemekle birlikte antlaşmaya bunu yavaş yavaş gerçekleştirebileceğimiz bir madde eklemişlerdir. Bu nedenle Ermeniler maksatlarına ulaşabilmek için bundan sonra daha fazla çalışmalıdırlar. Berlin Antlaşması gereğince Osmanlı Devleti, ertelemeksizin Ermenilerin durumunu iyileştirmeye mecburdur. Bu konuda bir gecikme meydana gelirse gerekli tedbirleri uygulamalıyı. Osmanl, Ermenistan'da gerekli teşkilat icraatını ve Ermenilerin yaşadı̆̆ yerlerde iyileştirmeler yapacağını taahhüt etmiştir, biz de bunu sağlamak için gayret etmeliyiz. Eğer aksi olursa bunu tatbik ettirmeye çalışmalıyız. Eğer meskûn şehirlerden birini ıslahattan hariç bırakırsa bunun icrası için de gayret etmeliyiz"s9". "Osmanl Devleti, Ermenileri, Kürt ve Çerkezlerden korumayı taahhüt etmiştir. Kürt ve Çerkezlerin cezalandırılması için gerekli tedbirleri almalıyız. Osmanl, Ermenistan'da yapacağı ıslahatı Avrupa'ya bildirmeye mecburdur. Islahat yapılmazsa bunları yaptırmaya çok gayret etmeliyiz. Avrupa, bunu kontrol edecektir. Eğer yeterli seviyede nezaret edilmemişse şikâyet etmeliyiz. Ermenistan, özellikle iyi idare ve himayeden mahrum ediliyor ise bu husustaki hukukumuzu ispatlamaliyı. Genelde Avrupa özelde Ingiltere Firat vadisiyle meşgul olmaktadır. Devletlerin menfaatleri rakiplerinin menfaatlerine aykırıdır. Bu rekabete sebep olan Ermeniler rekabetten çok fazla fayda elde etmelidir. Asırlardan beri unutulmuş olan Ermeni ismini, resmi bir antlaşmada kabul eden Büyük Devletlerden hukukumuzu talep etmek için vatanımızda, Osmanlı topraklarında ve Avrupa'da gerekli ortak tedbirleri uygulamalıyız. Zira millet içinde emniyetsizlik çıkaranlar Kürt ve Çerkezlerden daha fazla zararlidirlar. Berlin Konferansi'ndaki 61. maddenin semeresi nedir? Sorusuna cevap olarak denilmelidir ki 61 maddeden önce 60 madde yer almıştır. Yani dünyanın kanun ve düzeni gereğince önce büyükler kendi hisselerini alırlar, zayıflar ise türlü zorluklardan sonra hisselerini alabilirler. Bu nedenle 61. maddeyi gerçekleştirmek için herkes fedakârlık etmelidir.

Akademik

Bakış Kimse şikâyet etmeyip herkes kendinden sorumlu olmalıdır ${ }^{60}$. Çünkü Berlin Kongresi bize bir altın madeni vermiştir. Ermeniler, bu altın madenini meydana çıkarmaya çalışmalıdırlar. Patrik Efendi, Avrupa'ya bir mebus heyeti göndermekle milletin maddî ve manevî ihtiyaçlarınca gerekli olan bir harekette bulunmuştur ${ }^{6 !}$ ". Ermenilerin asıl isteği idari muhtariyetti. Fakat bu gerçekleşmedi. İşte Çeraz, bunun gerçekleşmemesine rağmen Berlin Antlaşması'na eklenen 61. Maddenin idari özerkliği gerçekleştirmek için bir adım olduğunu belirtmeye çalışmıştır. Bu andan itibaren Ermenilerin kendi milli menfaatleri için çalıştıkları doğrudur. 1914 yılında Minas Çeraz'ın

59 BOA, Fon Kodu: Y.PRK. A, Dosya No: 3, Gömlek No: 25, Belge. 5.

60 BOA, Fon Kodu: Y.PRK. A, Dosya No: 3, Gömlek No: 25, Belge. 6

$61 B O A$, Fon Kodu: Y.PRK. A, Dosya No: 3, Gömlek No: 25, Belge. 7 
Osmanlı Meclis-i Mebusan'ına Bitlis mebusu olarak girecek olması ${ }^{62}$ da millet olarak çalıştıklarının bir göstergesidir.

\section{Sonuç}

Ermeni Heyeti temsilcisi Mıgırdıç Kırımyan ile heyet tercümanı ve kâtibi Minas Çeraz, Berlin Kongresi'nden önce muhtar bir Ermenistan hayalinin gerçekleşmesi için Avrupa başkentlerinde çeşitli faaliyetlerde bulunmuş, İtalya, Fransa ve İngiltere'de önemli devlet adamlarılla görüşmüştür. Bu suretle Berlin Kongresi'nde büyük devletlerin Ermenilere destek vermelerini temine çalışmiştır.

Ermeni Meselesi'nin uluslar arası boyut kazanmasında ve Ermenilerin tanıtılmasında bu seyahatin önemi olduğu görülmektedir. Çeraz, seyahatin zorluğunu bilerek ve aynı zamanda vatandaşı oldukları Osmanlı Devleti'nin aleyhine faaliyet yaptıklarının da bilincinde olarak bu görevi kabul etmiştir. Kabulde milli hisleri etken olmuştur. Ermeni milliyetçiliği zaviyesinden bakıldığında bu işi kendi milli davaları için yaptıklarından dolayı herhangi bir yanlışlık yoktur. Ancak Osmanlı Devleti vatandaşı olan heyet üyelerinin kimlik değiştirerek İstanbul'dan ayrılmaya çalışması, üstelik Çeraz'ın kendi ifadesiyle zararlı evrak taşıdığını belirtmesi yaptıkları işin yanlışlığını ve kendilerinde vatandaşlık bilincinin çok da yerleşmediğini göstermektedir. Üstelik Rusya'ya ait bir vapurla İstanbul'dan ayrılamamalarının nedeni Rusya'nın koyduğu kural gereğidir. Yani Rusya, dini misyonu olan kişilerin Avrupa'ya gitmelerini istememektedir. Buna karşı Osmanlı Devleti'nin herhangi bir yaptırımı yoktur. Dolayısıyla burada baskı oluşturan unsurun Osmanlı Devleti olmadığı açıkça görülmektedir. Buna rağmen Osmanlı Devleti'nin baskı uygulamasından bahsetmesi yanlıştır. Zira bir baskı ortamı olsaydı Çeraz ve Kırımyan'ın hemen limanda tutuklanmaları gerekirdi. Yine Çeraz zararlı evrak taşıdığından bahsederek görevlerinin gizliliğine işaret etmiştir.

28 Şubat 1883 tarihli bir belgede Ermeni Patriği Nerses Efendi'nin Ermenilerin Osmanlı Devleti'ne sadakatle bağlı oldukları yazılıdır ${ }^{63}$. Hâlbuki zararlı belgeler taşıyarak gizli bir şekilde seyahat yapılabiliyorsa bu durumda Nerses'in belirttiği sadakatle bağlı olma sözünün içinin boş olduğunu veya menfaatler doğrultusunda sadakatten vazgeçilebileceğini vurgulamak gerekir.

Çeraz'ın seyahat notlarına bakıldığında zaman zaman ikilem içerisine girdiği ortadadır. Ermenilerin nüfusu konusu bunlardan biridir. Çünkü 5 milyon nüfus söylemi ile başlanmış görüştükleri bakanların reaksiyonu karşısında

62 Meclis-i Mebusan Zabıt Ceridesi, İkinci İnikad, 6 Kanunıevvel 1330 (1914), C. 1, Devre: 3, İçtima Senesi: 1, TBMM Kültür ve Sanat Yayınları, Ankara 1992, s. 15.

63 Osmanlı Belgelerinde Ermeni-Rus Ïlişkileri (1841-1898), C. I, Yayına Hazırlayanlar: Recep Karacakaya, Aziz Mahmut Uygun, Numan Yekeler, Seher Dilber ve diğerleri, Başbakanlık Devlet Arşivleri Genel Müdürlüğü Osmanlı Arşivi Daire Başkanlığı Yayınları, Ankara 2006, s. 33.

Akademik Bakış 253 Cilt 8 Sayl 16 Yaz 2015 
bu sayı Kırımyan'ın son sözleriyle 3 milyona düşürülmüştür. Ancak her aşamada Ermenilerin birlik ve beraberlik içerisinde hareket etmesi gerektiğinden bahsederek millet bilincine, milli duygulara temas etmiştir.

Çeraz, Berlin Kongresi sonrasında özerkliğin elde edilememesi karşısında yaşanılan üzüntü sonucu karamsar olunmaması gerektiğine önemle vurgu yaparak kongrenin faydalarını öne çıkarmayı düşünerek milletine umut aşılamaya çalışmıştır. Ayrıca Çeraz'ın notlarından Ermeni milletinin özerklik çabasının yeni olduğu, bu nedenle milletin henüz bilinçsiz olduğu anlaşılabilir. Zaten milletinin hakikatten şüphe etmemesi için ayrıntılı olarak notlarını yazdığını söylemiştir. Yine tecrübesizlik bakış açısıyla notlarının hemen hemen her safhasında Ermeni milletinin bundan sonra yapması gerekenleri öğüt verici bir üslupla tek tek anlatması Çeraz'ın millet bakış açısıyla bunları kaleme aldığını göstermiştir.

\section{KAYNAKLAR}

\section{ARŞIVLER}

Başbakanlık Osmanlı Arşivi, Fon Kodu: Yıldız Perakende Evrakı Sadaret Maruzatı (Y.PRK. A), 25/3, lef: 1-15.

BOA, Fon Kodu: Yıldız Sadaret Hususi Maruzat Evrakı (Y.A.HUS.), 169/43.

\section{RESMI YAYINLAR}

Meclis-i Mebusan Zabıt Ceridesi, İkinci İnikad, 6 Kanunıvvel 1330 (1914), C. 1, Devre: 3, İçtima Senesi: 1, TBMM Kültür ve Sanat Yayınları, Ankara 1992.

\section{TETKIK ESERLER}

\section{Kitaplar}

Akyol, Taha, Ortak Acr 1915 Türkler ve Ermeniler, Doğan Kitap, İstanbul Nisan 2009. Altınok, Salih, Belgeleriyle 19. ve 20. Yüzyıl Başlarında Ermeni Sorunu, Kozan Matbaacılık, Ankara Nisan 2007.

Attar, Aygün, Ermeni Ulusalcılı̆ııın Siyasal Oluşumu, Ermeni Araştırmaları II. Büyük Kongresi, Ankara 29-30 Mayıs 2004.

Bağçeci, Yahya, Ingiltere'de Ermeni Propagandası (1878- 1898), Yalın Yayıncılık, İstanbul 2013.

Bektaş, Hamza, Ermeni Soykırım İddiaları ve Gerçekler, Uludağ Üniversitesi Atatürk İlkeleri ve İnkılâp Tarihi Uygulama ve Araştırma Merkezi Yayınları, S.5, Bursa 2001.

Bilgi, Nejdet, Ermeni Tehciri ve Boğazlıyan Kaymakami Mehmet Kemal Bey'in Yargılanması, Kök Sosyal ve Stratejik Araştırmaları Serisi, S. 16, Ankara 1999.

Boray, Ferit Erden, Beyaz Ölüm Türkler ve Ermeniler, Kum Saati Yayınları, İstanbul 2004. Göyünç, Nejat, Türkler ve Ermeniler, Yeni Türkiye Yayınları, Ankara Şubat 2005. 
Gürün, Kamuran, Ermeni Dosyası, 7. Baskı, Remzi Kitabevi Yayınları, İstanbul 2005. Hocaoğlu, Mehmet, Arşiv Vesikalarıla Tarihte Ermeni Mezâlimi ve Ermeniler, Anda Dağıtım, İstanbul, 1976.

İlter, Erdal, Ermeni Kilisesi ve Terör, Kök Sosyal ve Stratejik Araştırmalar Merkezi Yayınları, S. 11, Ankara 1999.

İrtem, Süleyman Kani, Ermeni Meselesinin Ľç Yüzü, Haz: Osman Selim Kocahanoğlu, Temel Yayınları, İstanbul 2004.

Karacakaya, Recep, Kaynakçalı Ermeni Meselesi Kronolojisi (1878-1923), Başbakanlık Devlet Arşivleri Genel Müdürlüğü, Osmanlı Arşiv Daire Başkanlığı Yayınları, S. 52, İstanbul 2001.

Karpat, Kemal H., Osmanl Nüfusu (1830-1914) Demografik ve Sosyal Özellikleri, Çeviren: Bahar Tırnakçı, Tarih Vakfı Yurt Yayınları, İstanbul 2003.

Kılıç, Davut, Osmanlı İdaresindeki Ermeniler Arasındaki Dini ve Siyasi Mücadeleler, Avrasya Stratejik Araştırmalar Merkezi Yayınları, Ankara 2000.

Kodaman, Bayram, Ermeni Macerası (Tarihi ve Siyasi Bir Değerlendirme), Süleyman Demirel Üniversitesi Yayınları, S. 12, Isparta 2001.

Kodaman, Bayram, Türkler-Ermeniler ve Avrupa, Süleyman Demirel Üniversitesi Yayınları, S. 31, Isparta 2003.

Mazıcı, Nurşen, Uluslar Arası Rekabette Ermeni Sorununun Kökeni (1878 1920), Pozitif Yayınları, İstanbul Nisan 2005.

Melek, Kemal, Doğu Sorunu ve Milli Mücadelenin Dış Politikası, Der Yayınları, İstanbul 1985.

Metin, Halil, Türkiye'nin Siyasi Tarihinde Ermeniler ve Ermeni Olayları, MEB, Ankara 2001. Onur, Hüdavendigar, Ermeni Olayları Kronolojisi 2, Burak Yayınları, İstanbul 1999. Onur, Hüdavendigar, Ermeni Olayları Kronolojisi 3, Bilge Oğuz Yayınları, İstanbul Haziran 2006.

Osmanlı Belgelerinde Ermeni-Rus Iliş̧kileri (1841-1898), C. I, Yayına Hazırlayanlar: Recep Karacakaya, Aziz Mahmut Uygun, Numan Yekeler, Seher Dilber ve diğerleri, Başbakanlık Devlet Arşivleri Genel Müdürlüğü Osmanlı Arşivi Daire Başkanlığı Yayınları, Ankara 2006.

Öke, Mim Kemal, Ermeni Sorunu 1914 1923 ( Devletin Dış Politika Alternatifleri Üzerine Bir Inceleme), TTK Yayınları, Ankara 1991.

Öke, Mim Kemal, Musul Meselesi Kronolojisi (1918-1926), Türk Dünyası Vakfı Yayınları, İstanbul 1987.

Özçelik, İsmail, Ermeni Sorunu ve Gerçekler, Gündüz Eğitim Yayınları, Ankara 2005.

Saray, Mehmet, Ermenistan ve Türk-Ermeni İlişkileri, Atatürk Araştırma Merkezi Yayınları, Ankara 2005.

Seton-Watson, R. W, Disraeli, Gladstone, and the Eastern Questions, The Norton Library Printers, London 1972. 
Süslü, Azmi, Ermeniler ve 1915 Tehcir Olayı, Yüzüncü Yıl Üniversitesi Yayınları, Van, 1990.

Şahin, Eyüp, Yabancı Gözüyle Ermeni Meselesi, Askerlik Dairesi Başkanlığı Yayınları, Ankara 2001.

Şimşir, Bilal N, Ermeni Meselesi 1774-2005, 2. Baskı, Bilgi Yayınları, Ankara 2005. Uras, Esat, Tarihte Ermeniler ve Ermeni Meselesi, Belge Yayınları, İstanbul 1987.

\section{Makaleler}

Akçam, Taner, “Sevr ve Lozan'ın Başka Tarifi”, Imparatorluktan Cumhuriyete Türkiye'de Etnik Çatışma, Derleyen: Erik Jan Zürcher, İletişim Yayınları, İstanbul 2005.

Bağçeci, Yahya, "Osmanlı Belgelerine Göre Berlin Antlaşması'ndan I. Dünya Savaşı'na Kadar Fransa'nın Ermeni Politikası", Turkish Studies International Periodical For the Languages, Literature and History of Turkish or Turkic, Volume 5/4, Fall 2010, s. 1-25.

Bağçeci, Yahya, "İngiltere Başbakanı Lord Salisbury ve Ermeni Meselesi”, Erciyes Üniversitesi Sosyal Bilimler Enstitüsü Dergisi, Kayseri 2010, s.190-208.

Çelik, Recep, “Osmanlı Bürokrasisinde Görev Yapan Ermeniler”, Hoşgörü Toplumunda Ermeniler, C. 4, Yayına Hazırlayanlar: Metin Hülagü, Şakir Batmaz, Süleyman Demirci, Gülbadi Alan, Erciyes Üniversitesi Yayınları, Kayseri 2007, s. 27-53.

Günay, Bekir, "Değişen Dünya Denkleminde Sorunlu Türk Bölgeleri ve Çözüm Önerileri", Avrupa'dan Asya'ya Sorunlu Türk Bölgeleri, Derleyen: Bekir Günay, 1. Baskı, IQ Kültür ve Sanat Yayınları, İstanbul 2005.

İskefiyeli, Zeynep, “Osmanlı Devleti tarafından Ermenilere Verilen Nişan ve Madalyalar", Hoşgörü Toplumunda Ermeniler, C. 4, Yayına Hazırlayanlar: Metin Hülagü, Şakir Batmaz, Süleyman Demirci, Gülbadi Alan, Erciyes Üniversitesi Yayınları, Kayseri 2007, s. 573-592.

Kılıç, Davut, “XIX. Asırda İngiltere'nin Ortadoğu Politikasının Osmanlı Ermenilerine Yansıması", Dünden Bugüne Türk Ermeni İlişkileri, Edit: İdris BalMustafa Çufalı, Nobel Yayınları, Ankara 2003. Kocabaş, Süleyman, “1878 Berlin Antlaşması'ndan Sonra İngiltere'nin Politikası", Hoşgörü Toplumundan Yol Ayrımına Ermeniler, C. IV, Erciyes Üniversitesi Yayınları, Kayseri 2007, s.144-167.

Korkmaz, Seyfullah, "Osmanlı Toplumunda Birlikte Yaşama Anılarından Seçmeler", Hoşgörü Toplumunda Ermeniler, C. 4, Yayına Hazırlayanlar: Metin Hülagü, Şakir Batmaz, Süleyman Demirci, Gülbadi Alan, Erciyes Üniversitesi Yayınları, Kayseri 2007, s. 289-313.

Oflaz, Mustafa, İsmail Mangaltepe, "XIX. Yüzyıl Seyyahlarının Eserlerinde Ermeniler ve Türk-Ermeni İlişkileri", Hoşgörü Toplumunda Ermeniler, C. 4, Yayına Hazırlayanlar: Metin Hülagü, Şakir Batmaz, Süleyman Demirci, Gülbadi Alan, Erciyes Üniversitesi Yayınları, Kayseri 2007, s. 331-352. 
Oğuz, Ahmet, “Osmanlı İmparatorluğu'nda İlk Demokrasi Denemesi ve Ermeni Mebuslar", Hoşgörü Toplumunda Ermeniler, C. 4, Yayına Hazırlayanlar: Metin Hülagü, Şakir Batmaz, Süleyman Demirci, Gülbadi Alan, Erciyes Üniversitesi Yayınları, Kayseri 2007, s. 237-257.

Özşavlı, Halil, "Başlangıçtan I. Dünya Savaşına Kadar Rus-Ermeni İlişkileri”, The Journal of Academic Social Science Studies (JASSS), C. 5, S. 2, Nisan 2012, ss. 243-268.

Şehirli, Y. Atilla, "Osmanlı Devleti'nde İhtilalcı Ermeni Cemiyetlerinin Faaliyetleri ve Osmanlı Devleti'nin Aldığı Tedbirler", Dünden Bugüne Türk-Ermeni İlişkileri, Edit: İdris Bal-Mustafa Çufalı, Nobel Yayınları, Ankara 2003.

Uzun, Turgay, “Osmanlı Devleti'nde Milliyetçilik Hareketleri İçerisinde Ermeniler", Osmanlı'dan Günümüze Ermeni Sorunu, Editör: Hasan Celal Güzel, Yeni Türkiye Yayınları, Ankara 2000.

Yavuz, Fikrettin, "Ermeni Kimliğinin İnşasında Bir Patrik Portresi: Mıgırdıç Kırımyan", Akademik incelemeler, C.22, S.1, 2007, s. 1-33.

$\mathrm{Ek}-1^{64}$

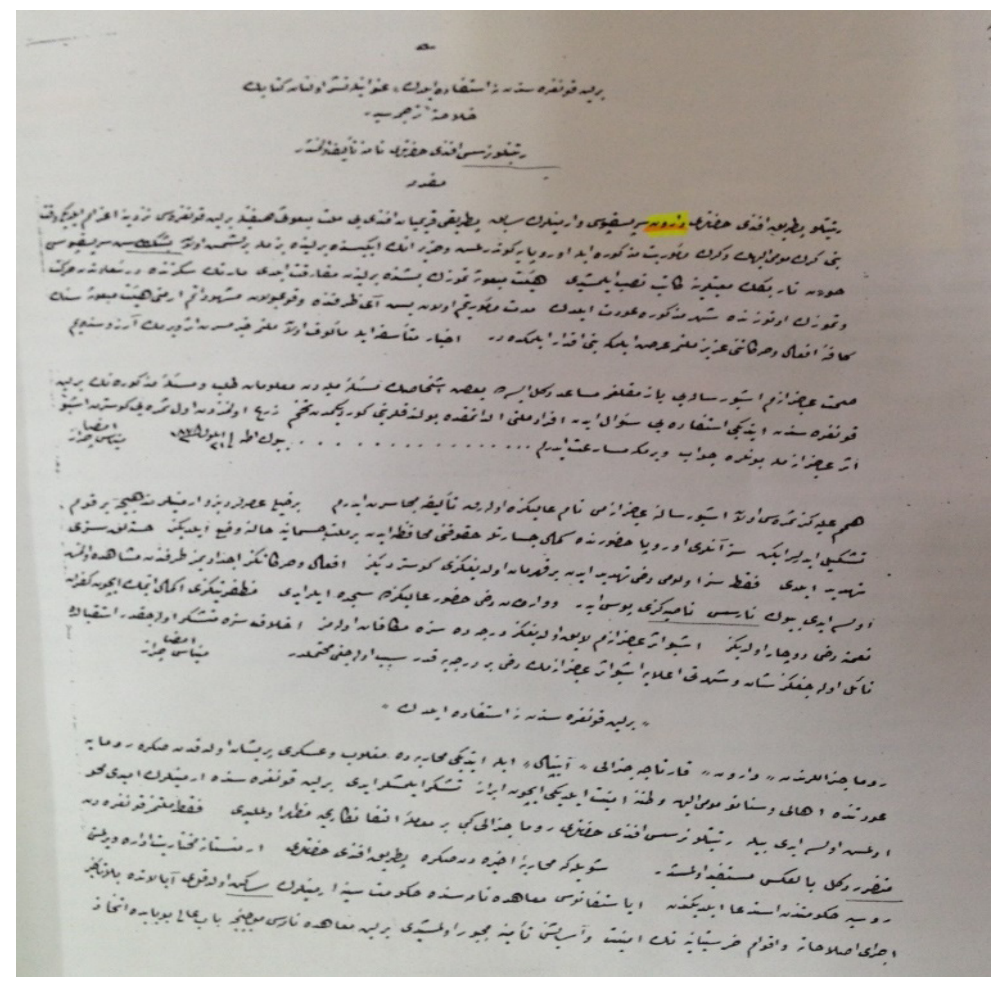

Akademik Bakı̧̧

257

Cilt 8 Sayı 16 Yaz 2015

$64 B O A$, Dosya No: 3, Gömlek No: 25, Fon Kodu: Y.PRK. A, Belge. 1. 
$\mathrm{Ek}-2^{65}$

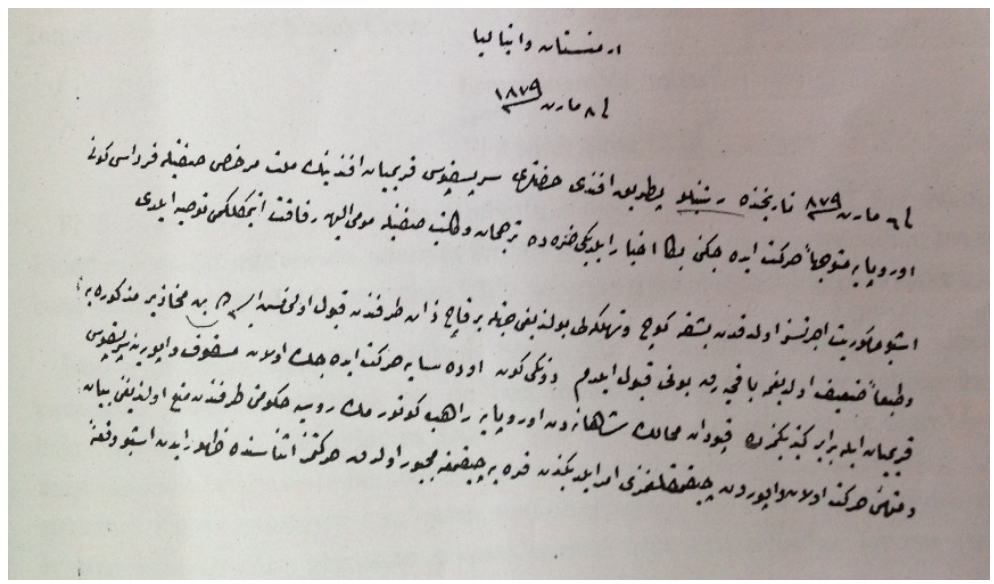

